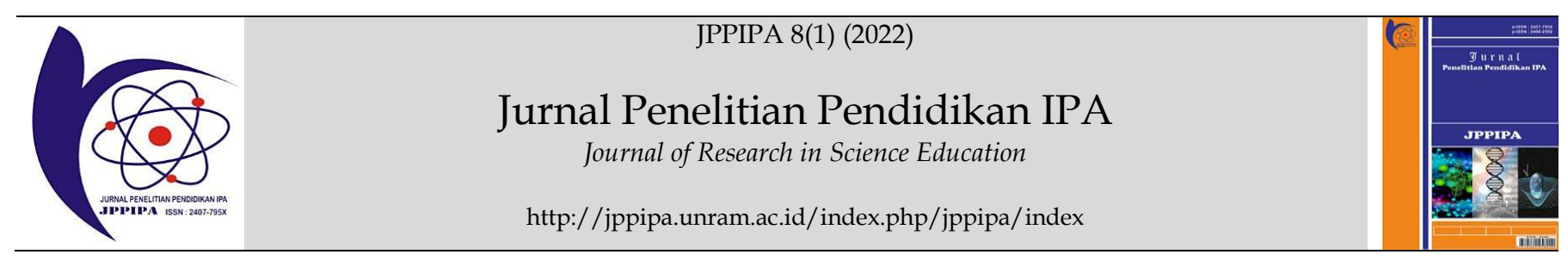

\title{
Detection of Knowledge Levels Related to Covid-19 Among State University Students, NKRI-RDTL Border Area
}

\author{
Yunawati Sele ${ }^{*}$, Fincensius Oetpah ${ }^{1}$, Vinsensia Ulia Rita Sila1 \\ ${ }^{1}$ Biology Education Study Program, Faculty of Education, Universitas Timor, Kefamenanu, Indonesia
}

DOI: $10.29303 /$ jppipa.v8i1.1079

\section{Article Info}

Received: October 31, 2021

Revised: January 2, 2022

Accepted: January 8, 2022

Published: January 31, 2022

\begin{abstract}
This research was conducted with the aim of revealing the level of knowledge related to COVID-19 among state university students, in the NKRI-RDTL border area. This study includes a qualitative descriptive study involving the population, namely all active students of state universities, Timor University, which are located in the border area of the Republic of Indonesia-RDTL. By using a simple random sampling technique, obtained 1181 students as respondents. The research instrument in the form of a knowledge questionnaire related to covid was distributed to respondents offline and also online using the google form. The results showed that $17.7 \%$ of respondents had knowledge at a low level, $62.66 \%$ of respondents had knowledge at a moderate level, while $19.64 \%$ of respondents had knowledge at a high level. Among the 4 aspects of knowledge, knowledge on the etiology and symptom aspects, as well as aspects of preventing the spread of covid-19, are at a high level with an average value of each aspect, namely 85.61 and 83.09. Meanwhile, knowledge on aspects of risk groups and aspects of the spread of COVID-19 is at a low level with an average value of 51.54 and 54.19 . This needs attention because the quality of knowledge basically has a relationship with attitudes and behavior related to COVID-19.
\end{abstract}

Keywords: Detection; Covid-19; Knowledge Level

Citation: Sele, Y., Oetpah, F., \& Sila, V.U.R. (2022). Detection of Knowledge Levels Related to Covid 19 Among State University Students, NKRI-RDTL Border Area. Jurnal Penelitian Pendidikan IPA, 8(1), 132-139. https://doi.org/10.29303/jppipa.v8i1.1079

\section{Introduction}

At the end of 2019 the world was shocked by the emergence of a virus that was reported to be different from the previous virus and the virus was a corona virus or known as covid 19. The corona virus was reported for the first time to appear and infect residents in Wuhan City, Hubei Province, China. The virus then spread widely and quickly so that it infected almost all countries in the world, including Indonesia. Corona virus infection can cause mild symptoms but can also cause death. Furthermore, the high number of infections and deaths due to the corona virus has made the world health agency, $\mathrm{WHO}$, designate corona virus infection as a global pandemic (Shereen, et al., 2020; Wang, et al., 2020; Mahase, 2020; Sohrabi, et al., 2020).
Specifically in East Nusa Tenggara, which is a province located in the border area between the Republic of Indonesia and the RDTL, cases of the spread of covid 19 have also been reported. The latest information regarding the spread of covid 19 is dated September 10, 2020 which can be seen on the website of the task force for the acceleration of handling covid 19 NTT, shows that NTT has 215 positive cases of covid 19. As for the details, 40 people are still being treated, 171 have been declared cured while 4 people have died. In addition, the number of suspected people is 2278 , with details of 76 people still being monitored, 2177 being monitored, while 25 people have died. Meanwhile, the total number of close contact cases is 3054 , with details of 450 people still being monitored and 2604 people being monitored.

\footnotetext{
*Email: yunawatisele@gmail.com
} 
In order to suppress the spread of the Covid-19 virus, the government continues to make various efforts. In Indonesia, one of the efforts made is to form a task force for handling covid 19 and appoint a spokesperson for covid (Surahmat, et al, 2021). The tasks that must be carried out are forming a communication team, appointing a spokesperson from the Ministry of Health who has articulation and the ability to deal with the media, creating a media center, creating a website as the main information reference, submitting national daily data periodically through press conferences and making communication and communication products. spreading other information about what covid 19 is, explanations for the prevention of the COVID-19 outbreak, protocols for handling people under surveillance until they are declared healthy and so on (Presidential Staff Office, 2020).

In particular, the appointment of a spokesperson for COVID-19 is aimed at ensuring proper public communication takes place. Communication that occurs through spokespersons is expected to create a calm society, and understand what they must do for their immediate environment, and build the public perception that the state is present and responsive in controlling crisis situations that occur. But in reality, the spread of news is not only through the official government website managed by the government and its spokespersons but through various other social media such as WhatsApp, YouTube, Twitter, and Facebook. Fauzi, et al (2020) explained that although the public has the right to access the information needed during the Covid-19 pandemic if the public does not have the correct knowledge, it will be difficult for the public to distinguish between true information and false information. This condition will eventually lead to wrong perceptions. In line with that, DeLuca, (2020) explained that the spread of hoax news will cause people to experience confusion and fear and trigger people to carry out behaviors that are not included. To arise from the spread of fake news related to covid 19, the public must have high knowledge. One of the elements of society that has the responsibility to increase their level of knowledge about COVID-19 is the student. It is hoped that with a high level of knowledge, students as agents of change can contribute to reducing the anxiety caused by the spread of fake news about covid 19. Overcoming fears and panic that may arise

Furthermore, if studied properly, it can be seen that the level of knowledge about COVID-19 can be influenced by various factors. These factors include the level of education, the type of information, cultural conditions and experiences experienced by the community (Notoatmodjo, 2010; Kapur, 2018; Yanti, et al, 2020). In addition, Ahmadi, (2013) explains that basically the reactions and decisions taken by a person in behaving are largely determined by the information obtained based on personal experience or experience obtained based on observations of the surrounding environment.

The existence of factors that affect the level of knowledge about COVID-19 as described above shows that people, including students, in different environments have the potential to have different levels of knowledge. In particular, state university students, who are in the NKRI-RDTL border area, namely students in East Nusa Tenggara have the potential to have a different level of knowledge about COVID-19 from students outside the border area where this is based on differences in the type and speed of exchange information, cultural conditions and experiences regarding Covid-19 cases that occurred in the surrounding environment, namely in North Central Timor Regency and other regencies in the East Nusa Tenggara province or cases that occurred in neighboring countries, namely Timor Leste.

This research is important because by detecting the level of knowledge about COVID-19 among state university students, the NKRI-RDTL border area, an overview of the level of knowledge can be obtained. This picture can then be used as a basis for policymakers to break the chain of the spread of COVID-19.

\section{Method}

This research was conducted in June-July 2021 and is a qualitative descriptive study. The population in this study are all active students of state universities, Timor University, which are located in the NKRI-RDTL border area, totaling 6825 people. The sampling technique is simple random sampling with the number of samples taken being $15-25 \%$ of the population. This refers to the opinion of Arikunto, (2006) which explains that if the research subjects are less than 100, it is better to take all of them so that the research is a population study. But if the number of subjects is large (more than 100 people) it can be taken between $10-25 \%$ or more. The instrument used in this study was a knowledge questionnaire related to covid 19 developed by Saefi, et al., (2020). The questionnaire consists of the demographic information section of the respondents and the knowledge section about COVID-19 which consists of 18 statement items covering aspects of knowledge about the etiology and symptoms of risk groups, spread, and prevention. The statements related to these aspects can be seen in Table 1. Respondents were asked to provide responses to each statement with response options namely yes, no, and don't know. 
Table 1. Statements in the knowledge questionnaire related to covid-19

\begin{tabular}{|c|c|}
\hline Aspect & Statement \\
\hline \multirow{4}{*}{$\begin{array}{l}\text { Etiology and } \\
\text { symptoms }\end{array}$} & Covid-19 is a disease caused by the corona virus \\
\hline & The main clinical symptoms of COVID-19 are fever, fatigue, dry cough and myalgia \\
\hline & There are also people with COVID-19 who do not show any symptoms, called people without symptoms \\
\hline & Not everyone with COVID-19 has a worsening condition, except for those who are elderly \\
\hline \multirow[t]{3}{*}{ Risk group } & $\begin{array}{l}\text { People with COVID-19 who have chronic diseases such as diabetes, heart disease and obesity have an } \\
\text { increasingly severe condition. }\end{array}$ \\
\hline & $\begin{array}{l}\text { Children and teenagers do not need to make efforts to prevent Covid-19 infection because they have a good } \\
\text { immune system }\end{array}$ \\
\hline & People who have a high immune system will not be infected with Covid-19 \\
\hline \multirow[t]{6}{*}{ Deployment } & $\begin{array}{l}\text { There are also people with COVID-19 who do not show symptoms, or people without symptoms } \\
\text { cannot transmit the viral infection to others. }\end{array}$ \\
\hline & Covid-19 spreads through respiratory droplets of people infected with Covid-19. \\
\hline & $\begin{array}{l}\text { The bodies of people with COVID-19 who have not been buried can be a source of the spread of the Covid-19 } \\
\text { virus. }\end{array}$ \\
\hline & $\begin{array}{l}\text { The bodies of people with Covid-19 who have been buried can be a source of the spread of the Covid-19 } \\
\text { virus. }\end{array}$ \\
\hline & Covid-19 cannot penetrate cloth masks commonly used by the general public. \\
\hline & Covid-19 only spreads through objects, not through the air. \\
\hline \multirow[t]{5}{*}{ Prevention } & There is currently no effective cure for COVID-19 but treatment and intensive care can help people with \\
\hline & $\begin{array}{l}\text { To prevent COVID-19 infection, we must avoid traveling to crowded places such as markets and tourist } \\
\text { attractions and avoid using public transportation. }\end{array}$ \\
\hline & Not traveling between cities can prevent the spread of COVID-19. \\
\hline & The transmission of the COVID-19 virus can be prevented by not touching your face. \\
\hline & $\begin{array}{l}\text { Isolation and treatment of people infected with the COVID-19 virus is an effective way to reduce the spread } \\
\text { of the virus. }\end{array}$ \\
\hline
\end{tabular}

This research was conducted through three stages. There are two activities carried out in the first stage, namely population and sample identification and preparing research instruments. In the second stage, questionnaires have distributed either face-to-face or via a google form. Meanwhile, in the third stage, data analysis was carried out using descriptive statistics. The description of the research procedure can be seen in Figure 1.

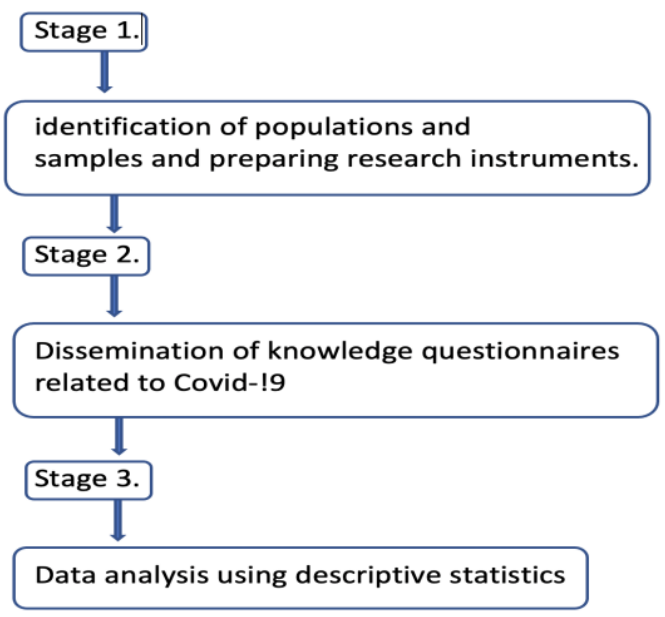

Figure 1. Research Procedure related to Covid-19
The data collected were analyzed using descriptive statistics. The demographic data of the respondents consisted of gender, the origin of the faculty, the origin of the study program, and length of study, while data on knowledge related to COVID-19 consisted of etiology and symptoms, risk groups, spread, and prevention. Each correct answer on knowledge is given a value of 1 while a value of 0 for wrong answers. Furthermore, the determination of the level of knowledge can be seen in Table 2.

Table 2. Level of Knowledge Related to Covid-19

\begin{tabular}{ll}
\hline Persentage $(\%)$ & Level \\
\hline $80-100$ & High \\
$60-79$ & Medium \\
$<60$ & Low \\
\hline
\end{tabular}

Fauzi, et al, 2020

\section{Result and Discussion}

Timor University is a public university located in the border area between Indonesia and Timor Leste. The University of Timor has 4 faculties with 16 study programs. The number of active students at the University of Timor in the even semester of 2020/2021 is 6825 students. To reveal the level of students' knowledge of covid 19, a research instrument has been distributed in the form of a knowledge questionnaire 
related to covid 19 to be filled out by respondents as can be seen in Figure 2.

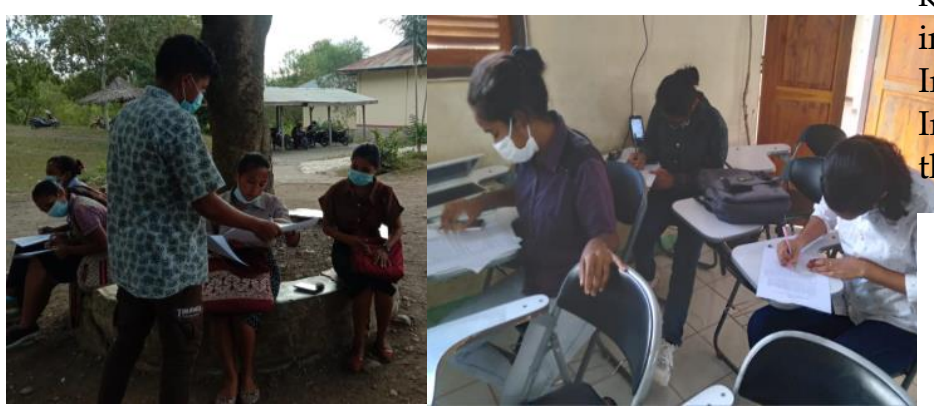

Figure 2. Distribution and Filling of Questionnaires

After distributing the questionnaires offline and online, the data obtained from 1181 respondents with the details of the respondents can be seen in Table 3.

Table 3. Demographic Data of Respondents

\begin{tabular}{|c|c|c|}
\hline Variable & Freq (n) & $(\%)$ \\
\hline \multicolumn{3}{|l|}{ Gender } \\
\hline Man & 323 & 27.35 \\
\hline Woman & 858 & 72.65 \\
\hline \multicolumn{3}{|l|}{ Faculty } \\
\hline $\begin{array}{l}\text { Faculty of Social Science and Political } \\
\text { Science }\end{array}$ & 238 & 20.15 \\
\hline Faculty of Science Education & 352 & 29.81 \\
\hline Faculty of Economics & 226 & 19.14 \\
\hline Faculty of Agriculture & 365 & 30.91 \\
\hline \multicolumn{3}{|l|}{ Study program } \\
\hline Public administration & 135 & 11.43 \\
\hline Public Administration Ilmu & 103 & 8.72 \\
\hline Mathematics education & 48 & 4.06 \\
\hline Biology Education & 170 & 14.39 \\
\hline English language education & 80 & 6.77 \\
\hline $\begin{array}{l}\text { Indonesian language and literature } \\
\text { education }\end{array}$ & 54 & 4.57 \\
\hline Economic development & 99 & 8.38 \\
\hline Management & 127 & 10.75 \\
\hline Agrotechnology & 43 & 3.64 \\
\hline Agribusiness & 38 & 3.22 \\
\hline farm & 105 & 8.89 \\
\hline Information Technology & 65 & 5.50 \\
\hline Biology & 45 & 3.81 \\
\hline Chemical & 21 & 1.78 \\
\hline Mathematics & 30 & 2.54 \\
\hline Nursing & 18 & 1.52 \\
\hline \multicolumn{3}{|l|}{ Study Length } \\
\hline 2 Semester & 443 & 37.51 \\
\hline 4 Semester & 227 & 19.22 \\
\hline 6 Semester & 215 & 18.20 \\
\hline 8 Semester & 176 & 14.90 \\
\hline 10 Semester & 103 & 8.72 \\
\hline 12 Semester & 17 & 1.44 \\
\hline
\end{tabular}

Based on the results of the analysis of the answers given by the respondents, the students' knowledge has an average value of 68.76 . This value indicates that the knowledge of students in the Indonesia-NKRI border area is in the medium category. In detail, the percentage of respondents according to their level of knowledge can be seen in Figure 3.

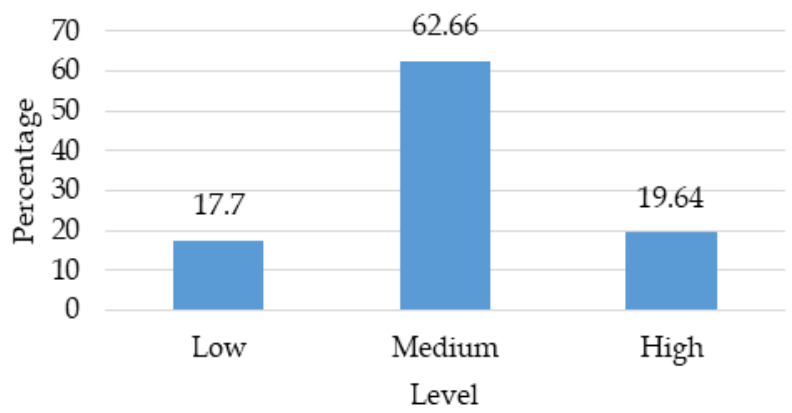

Figure 3. Knowledge Level Regarding Covid-19

Based on the data in Figure 3. it can be seen that as many as $17.7 \%$ of respondents have knowledge at a low level, $62.66 \%$ of respondents have knowledge at a medium level and $19.64 \%$ of respondents have knowledge at a high level. This shows that most state university students in the NKRI-RDTL border area do not yet have knowledge at a high level. Specifically, several previous studies have reported that one of the things that can affect a person's level of knowledge is the quality of health literacy. Health literacy can be interpreted as the ability to explore and analyze health information that can be used as a basis for making the right decisions according to existing health instructions and rules (Pleasant \& McKinney, 2011). Ranaweera, (2017) and Fauzi, et al., (2020) explain that various health-related information including covid 19 can be obtained, understood, analyzed, and used properly by someone if that person has high health literacy. In line with that, An, et al., (2021) and Silva \& Santos, (2021) reported that there was a close relationship between the quality of knowledge about COVID-19 and the quality of health literacy possessed by a person. People with low health literacy tend to have low knowledge about COVID-19 as well.

Efforts to empower a person's health literacy quality can be determined by several things, for example, academic ability and the ability to access and interpret health information, including information about COVID-19. Soleymani, (2014) and Wolf, (2012) explained that the higher the quality of a person's academic ability, the higher the ability to access, interpret and verify the truth of various health information. This condition will make the individual have a high quality of health literacy, including literacy related to covid 19 . On the other hand, the ability to 
access and interpret information related to covid-19 is closely related to the ability to access information from valid and credible sources and not just limited to on access to information on social media which is generally not known with certainty regarding the validity and credibility of the information. This is in accordance with the opinion of Chen, et al., (2018) and Ghaddar, et al., (2012) which state that a credible source of information is one of the important factors that determine the quality of a person's health literacy. Furthermore, in detail, the knowledge profile of state university students in the NKRI-RDTL border area for each aspect of knowledge, namely knowledge related to etiology and symptoms, knowledge related to risk groups, knowledge related to the spread of covid-19, and knowledge related to efforts to prevent the spread of covid 19 can be seen in Figure 4 .

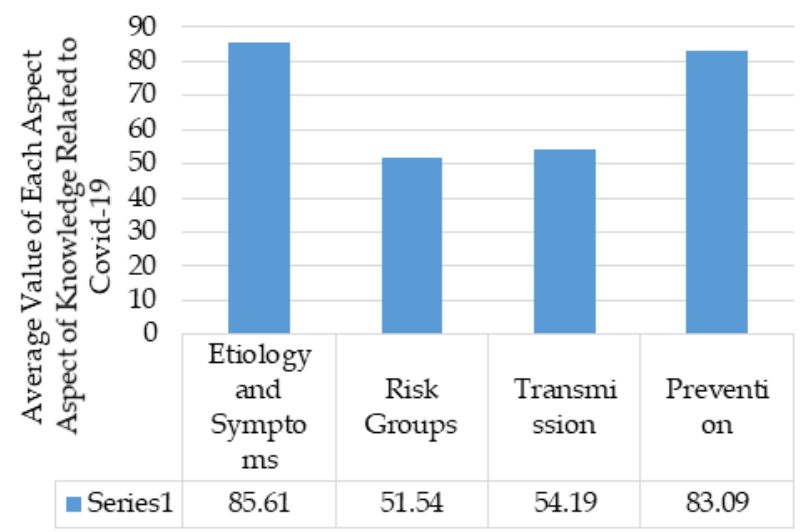

Figure 4. Average Value of Each Aspect of Knowledge Related to Covid-19

Based on the data shown in Figure 4, it can be seen that for aspects of knowledge about the etiology and symptoms as well as aspects of knowledge about efforts to prevent the spread of COVID-19, state university students in the NKRI-RDTL border area have knowledge at a high level with an average value of each. -each aspect is 85.61 and 83.09. As for the aspect of knowledge about the etiology and symptoms, most students have high knowledge of the fact that covid-19 is caused by a corona virus, the main clinical symptoms of covid-19 are fever, fatigue, dry cough, and myalgia, people with covid-19 are also present. Those who do not show symptoms are called People without Symptoms and not everyone with COVID-19 has a more severe condition, except for those who are elderly. As for the aspect of knowledge about efforts to prevent the spread of covid-19, most students already have high knowledge that currently there is no effective drug for covid-19 but treatment and intensive care are able to help people with covid-19 to recover. Isolation and treatment of people infected with the COVID-19 virus is also an effective way to reduce the spread of the virus. Furthermore, prevention of the spread of COVID-19 can be done by continuing to implement health protocols including not touching your face, avoiding the habit of traveling to crowded places and traveling between cities, and avoiding the use of public transportation.

The facts obtained through this study about the high knowledge of students on the etiology and symptom aspects as well as aspects of knowledge about efforts to prevent the spread of COVID-19 indicate that students have understood the relationship between the corona virus and the human respiratory system. Chen, et al., (2020), Lu, et al., (2020), and Zhong, et al., (2020) explain that covid-19 is a respiratory disease caused by a corona virus infection, can spread quickly, and can have various impacts ranging from mild to severe impact, depending on the condition of the sufferer. In general, corona virus infection can cause disturbances in all components of the respiratory system so that it can cause adverse effects on other organ systems (Biscardi, 2020; Brosnahan, et al, 2020). Furthermore, Cucinotta \& Vanelli (2020) explained that the public can be actively involved in efforts to prevent the spread of COVID-19 by implementing strict health protocols.

Although the average value of knowledge of state university students in the NKRI-RDTL border area for aspects of the etiology and symptoms as well as aspects of preventing the spread of covid-19 has shown that for these two aspects students have knowledge at a high level, but based on the data in Figure 2. From this, it can also be seen that for the aspect of knowledge about risk groups as well as for aspects of the spread of covid-19, students still have knowledge in the low category where the average value for each aspect is 51.54 and 54.19. For the aspect of knowledge about risk groups, state university students in the NKRI-RDTL border area still have low knowledge regarding the fact that children and adolescents also need to make efforts to prevent covid 19, people with high immune systems can also be infected with covid-19 and other people with high immunity with covid-19 who have chronic diseases such as diabetes, heart disease and obesity have increasingly severe conditions. As for the aspect of knowledge about the spread of covid-19, students still have low knowledge about the fact that people without symptoms can transmit the corona virus to others, the corona virus can spread through respiratory droplets of people who have been infected and the corona virus can spread through the air not only through certain objects held by COVID-19 sufferers. In addition, the bodies of people with COVID-19 who have not been buried can be a source of spreading the Covid-19 virus. The facts regarding the low level of student knowledge 
on aspects of knowledge about the spread of COVID-19 as revealed through this study are also in line with previous research reported by Limbong, et al (2021), Saefi, et al., (2020) \& Singh, et al., (2020). Based on these studies, it is found that most students do not understand well that the corona virus can spread in various ways, including through the bodies of infected people. This fact needs attention because knowledge about the transmission of COVID-19 is the basis for implementing various methods of preventing the transmission of COVID-19, such as wearing masks, washing hands with soap, physical distancing, and various other methods related to the implementation of health protocols.

In addition to being related to efforts to prevent the spread of COVID-19, the fact that the knowledge of state university students in the NKRI-RDTL border area has not been optimal needs to get attention from various related parties because knowledge related to COVID-19 has a positive correlation with attitudes and behaviors shown in responding to the COVID-19 pandemic. 19. Al-Hanawi, et al., (2020) explained that in general there is a relationship between knowledge, attitudes and behavior related to covid 19 owned by the community where the high and low levels of knowledge, attitudes and knowledge about covid 19 will determine the quality of efforts to prevent the spread of covid 19. Furthermore, Yanti, et al., (2020) explained that a positive attitude in suppressing the spread of covid 19 was marked by awareness to comply with government policies related to the implementation of social distancing, social distancing and physical distancing, while good behavior was related to the implementation of health protocols such as the use of masks, routine washing hands with running water and soap or using hand sanitizer, avoiding the habit of touching the face, following coughing and sneezing etiquette and various other health protocols

\section{Conclusion}

Based on the results of data analysis and discussion, it can be seen that most state university students in the NKRI-RDTL border area have a moderate level of knowledge. In detail, $17.7 \%$ of respondents have knowledge at a low level, $62.66 \%$ of respondents have knowledge at a moderate level, while $19.64 \%$ of respondents have knowledge at a high level. Among the 4 aspects of knowledge, knowledge on the etiology and symptom aspects as well as aspects of preventing the spread of covid-19 are at a high level with an average value of each aspect, namely 85.61 and 83.09. Meanwhile, knowledge on aspects of risk groups and aspects of the spread of COVID-19 is at a low level with an average value of 51.54 and 54.19.

\section{Acknowledgments}

The author would like to thank the Institute for Research and Community Service, the University of Timor as the funder who has facilitated and assisted the implementation of this research.

\section{References}

Ahmadi. (2013). Kesehatan Masyarakat, teori dan aplikasi. Jakarta: Raja Grafindo

Al-Hanawi, M. K., Angawi, K., Alshareef, N., Qattan, A., Helmy, H. Z., Abudawood, Y., Alqurashi, M., Kattan, W. M., Kadasah, N. A., Chirwa, G. C., \& Alsharqi, O. (2020). Knowledge, Attitude and Practice Toward COVID-19 Among the Public in the Kingdom of Saudi Arabia: A Cross-Sectional Study. Frontiers in public health, 8, 217. https://doi.org/10.3389/fpubh.2020.00217

An, L., Bacon, E., Hawley, S., Yang, P., Russell, D., Huffman, S., \& Resnicow, K. (2021). Relationship Between Coronavirus-Related eHealth Literacy and COVID-19 Knowledge, Attitudes, and Practices among US Adults: Web-Based Survey Study. Journal of medical Internet research, 23(3), e25042. https://doi.org/10.2196/25042

Arikunto, S. (2006). Metode Penelitian Kualitatif. Jakarta: Bumi Aksara

Biscardi A. (2020). Coronavirus Impacts on Respiratory System and its Phases. Medical Reports and Case Studies. 5(4). Retrieved from: https://www.iomcworld.org/abstract/....html

Brosnahan, S. B., Jonkman, A. H., Kugler, M. C., Munger, J. S., \& Kaufman, D. A. (2020). COVID19 and Respiratory System Disorders: Current Knowledge, Future Clinical and Translational Research Questions. Arteriosclerosis, thrombosis, and vascular biology, 40(11), 2586-2597. https://doi.org/10.1161/ATVBAHA.120.314515

Chen, N, Zhou M, Dong X, Qu J, Gong F, Han Y, et al. (2020). Epidemiological and Clinical Characteristics of 99 Cases of 2019 Novel Coronavirus Pneumonia in Wuhan, China: a Descriptive Study. Lancet. 395: 507-513. https://doi.org/10.1016/S0140-6736(20)30211-7

Chen, X., Hay, J. L., Waters, E. A., Kiviniemi, M. T., Biddle, C., Schofield, E., ... Orom, H. (2018). Health Literacy and Use and Trust in Health Information. Journal of Health Communication, 23(8),

724-734. https://doi.org/10.1080/10810730.2018.1511658

Cucinotta, D., \& Vanelli, M. (2020). WHO Declares COVID-19 a Pandemic. Acta Bio-Medica: Atenei 
Parmensis,

91(1),

$157-160$.

https://doi.org/10.23750/abm.v91i1.9397

DeLuca, E. (2020). Countries with lower literacy levels need different COVID-19 communication strategies. Retrieved from: https://translatorswithoutborders.org/blog/lite racy-levels-covid-19/

Fauzi, A., Husamah, H., Miharja, F. J., Fatmawati, D., Permana, T. I., \& Hudha, A. M. (2020). Exploring COVID-19 Literacy Level among Biology Teacher Candidates. Eurasia Journal of Mathematics, Science and Technology Education, 16(7), em1864. https://doi.org/10.29333/ejmste/8270

Ghaddar, S. F., Valerio, M. A., Garcia, C. M., \& Hansen, L. (2012). Adolescent health literacy: The importance of credible sources for online health information. Journal of School Health, 82(1), 28-36. https://doi.org/10.1111/j.17461561.2011.00664.x

Kantor Staf Presiden. (2020). Penanganan Covid 19, Protokol Komunikasi Publik. Retrieved from: (http:/ / ksp.go.id/wp-...Komunikasi-COVID19.pdf

Kapur, R. (2018). Impact of Culture on Education. Retrieved from: https://www.researchgate.net/publication/323 794724_Impact_of_Culture_on_Education.

Limbong, J.D.M., Kuswinarti, K., \& Sitorus, T. (2021). Knowledge, Attitude, and Practices towards the COVID-19 Pandemic among Undergraduate Students. Althea Medical Journal. 8(2): 70-76 https://doi.org/10.15850/amj.v8n2.2282

Lu, H., Stratton C.W., \& Tang, Y.W. (2020). Outbreak of Pneumonia of Unknown Etiology in Wuhan China: the Mystery and the Miracle. J Med Virol, 92(4),

401-402.

https://doi.org/10.1002/jmv.25678.

Mahase, E. (2020). Covid-19: WHO declares pandemic because of "alarming levels" of spread, severity, and inaction. BMJ (Clinical Research Ed.), 368(m1036),

https://doi.org/10.1136/bmj.m1036

Notoatmodjo, S. (2010). Ilmu Perilaku Kesehatan.Jakarta : Rineka cipta

Pleasant, A., \& McKinney, J. (2011). Coming to consensus on health literacy measurement: An online discussion and consensus-gauging process. Nursing Outlook. 59(2). 95-106. https://doi.org/10.1016/j.outlook.2010.12.006

Ranaweera, P. (2017). Importance of information literacy skills for an information literate society. National Institute of Library \& Information Sciences, University of Colombo, 1-13. Retrieved from: http://hdl.handle.net/10760/11956
Saefi, M., Fauzi, A., Kristiana, E., Adi, W.C., Muchson, M., Setiawan, M.E., Islami, N.N., Ningrum, A.E.A.F., Ikhsan, M.A., \& Ramadhani, M. (2020). Survey data of COVID-19 related knowledge, attitude, and practices among Indonesian undergraduate students. Data Brief; (31)20200801. https://doi.org/10.1016/j.dib.2020.105855

Shereen, M.A., Khan, M., Kazmi, S., Bashir, A., \& Siddique, N. (2020). COVID-19 infection: Origin, transmission, and characteristics of human coronaviruses. Journal of Advanced Research, 24, 91-98. https://doi.org/10.1016/j.jare.2020.03.005

Silva, M.J \& Santos, P. (2021). The Impact of Health Literacy on Knowledge and Attitudes towards Preventive Strategies against COVID-19: A Cross-Sectional Study. Int. J. Environ. Res. Public Health. 18 ,

5421. https://doi.org/10.3390/ijerph1810541

Singh, J.P., Sewda, A., \& Shiv, D. G. (2020). Assessing the Knowledge, Attitude and Practices of Students Regarding the COVID-19 Pandemic. Journal of Health Management, 22(2), 281-290. https://doi.org/10.1177/0972063420935669

Sohrabi, C., Alsafi, Z., Neill, N. O., Khan, M., Kerwan, A., Al-jabir, A., Agha, R. (2020). World Health Organization declares global emergency: A review of the 2019 novel coronavirus (COVID19). International Journal of Surgery, 76, 71-76. https://doi.org/10.1016/j.ijsu.2020.02.034

Soleymani, M. R. (2014). Investigating the relationship between information literacy and academic performance among students. Journal of Education and Health Promotion, 3, 95. https://doi.org/10.4103/2277-9531.139677

Surahmat, A., Dida, S., \& Zubair, F. (2021). Analisis Wacana Strategi Komunikasi Krisis Pemerintah Menangani Covid-19. Jurnal Komunikasi, 13 (1), 36-53. http://dx.doi.org/10.24912/jk.v13i1.9272

Wang, H., Wang, Z., Dong, Y., Chang, R., Xu, C., Yu, X., Cai, Y. (2020). Phase-adjusted estimation of the number of Coronavirus Disease 2019 cases in Wuhan, China. Cell Discovery, 6(1), 4-11. https://doi.org/10.1038/s41421-020-0148-0

Wolf, M. S., Curtis, L. M., Wilson, E. A. H., Revelle, W., Waite, K. R., Smith, S. G., ... Baker, D. W. (2012). Literacy, cognitive function, and health: Results of the LitCog study. Journal of General Internal Medicine, 27(10), 1300-1307. https://doi.org/10.1007/s11606-012-2079-4

Yanti, B., Mulyadi, E., Wahiduddin, W., Novika, R.G.H., Arina, Y.M.D., Martani, I.S., \& Nawan. (2020). Community Knowledge, Attitudes, And Behavior Towards Social Distancing Policy As A Means Of Preventing Transmission Of Covid-19 In Indonesia. Jurnal Administrasi Kesehatan 
Indonesia.

$8(2)$ :

4.

https://doi.org/10.20473/jaki.v8i2.2020.4-14

Zhong, B., Luo, W., Li, H., Zhang, Q., Liu, X., Li, W., \& Li, Y. (2020). Knowledge, Attitudes, and Practices toward COVID-19 among Chinese Residents during Rapid Rise Period of COVID-19 Outbreak: a Quick Online Cross Sectional Survey. International Journal of Biological Sciences, 16(10),

1745-1752.

https://doi.org/10.7150/ijbs.45221 